\title{
Preliminary study on the dye removal efficacy of immobilized marine and freshwater microalgal beads from textile wastewater
}

\author{
S. Dinesh Kumar, P. Santhanam*, R. Nandakumar, S. Ananth, B. Balaji Prasath, A. Shenbaga \\ Devi, S. Jeyanthi, T. Jayalakshmi and P. Ananthi
}

Marine Planktonology and Aquaculture Laboratory, Department of Marine Science, School of Marine Sciences, Bharathidasan University, Tiruchirappalli-620 024, Tamil Nadu, India.

Received 6 September, 2013; Accepted 16 May, 2014

\begin{abstract}
Discharge of textile wastewater containing toxic dyes can adversely affect aquatic organisms and human health. The objective of the study was to investigate the potential of immobilized marine microalgae (Chlorella marina, Isochrysis galbana, Tetraselmis sp. Dunaliella salina and Nannochloropsis sp.) and freshwater microalga (Chlorella sp.) in removing dye from textile wastewater (TW). The present study incorporated the use of $2 \%$ sodium alginate matrixes for decoloration. Among the algal species tested, the highest colour removal was noticed in Isochrysis galbana (55\%) followed by freshwater Chlorella sp. (43\%). The present method is easy to use, cost effective and devoid of technical problems.
\end{abstract}

Key words: Marine microalga, immobilization, textile wastewater, Chlorella marina, Isochrysis galbana, Dunaliella salina, biosorption, bioremediation.

\section{INTRODUCTION}

Biosorption is one of the most innovative technologies to remove contaminants from the aqueous solution and wastewaters. Textile industrial wastewaters are characterized with high amount of biochemical oxygen demand (BOD), total suspended solid (TSS), chemical oxygen demand (COD), alkalinity and total dissolved solids (Kaushik and Malik, 2009). Therefore, degradation of wastes from these industrial discharges becomes difficult (Fewson, 1998). These dyes cause problems to human health, because they have toxic, carcinogenic and even mutagenic compounds that pose a serious hazard to aquatic organisms (Ozer et al., 2005). Dyes can be segregated as anionic (direct, acid and reactive dyes); cationic (basic dyes); and nonionic (disperse dyes). The chromophores in anionic and nonionic dyes mostly consist of azo groups or anthraquinone types.

Anthraquinone based dyes are more resistant to degradation due to their fused aromatic structures. The 
metal complex dyes are mostly based on chromium. Dye wastewater is usually treated by physical or chemical treatment processes. These include flocculation combined with flotation, electro flocculation, membrane filtration, electro kinetic coagulation, electrochemical destruction, ion-exchange, irradiation, precipitation, ozonation, and katox treatment method involving the use of activated carbon and air mixtures. However, these technologies are generally ineffective in color removal, expensive and less adaptable to a wide range of dye wastewaters (Banat et al., 1996). Adsorption, especially immobilization has been observed to be an effective process for color removal from dye wastewater because, immobilization of the biomass overcomes many of these problems. Amongst the various immobilization methods, encapsulation (whereby the biomasses are enclosed within a polymeric matrix) is one of the most commonly used methods. In addition to that, the immobilization matrix is suitable for practical use in biosorption; it must be mechanically strong and chemically stable to withstand actual process conditions. Mass transfer considerations are also of paramount importance: the matrix must be sufficiently porous to enable diffusion of the sorbate to the sorbent surface. The ability of the gel matrix to facilitate diffusion of sorbate is also influenced by the size and shape of the immobilization gels (Jen et al., 1996). Microalgae have been shown to be capable of removing colour from various dyes through mechanisms such as biosorption, bioconversion and bioagulation (Khalaf, 2008), microalgae can be a better choice for bioremediation compared to other microorganisms owing to their photosynthetic capabilities, thereby absorbing $\mathrm{CO}_{2}$ from atmosphere and converting solar energy into useful biomasses and incorporating nutrients and other pollutants.

Several workers have reported dye removal potential of freshwater algae (Acuner and Dilek, 2004; Dhaneshwar et al., 2007; Khalaf, 2008). However, very few attempts have been made by some workers using marine algae for dye removal (Mubarak et al., 2011; Soumya, 2012; Henciya et al., 2013). The objective of the present attempt was to investigate the efficiency of some marine (Chlorella marina, Isochrysis galbana, Tetraselmis sp., Nannochloropsis sp. and Dunaliella salina) and freshwater microalgal cells (Chlorella sp.) in dye removal from the textile effluent. This is the first report for dye removal by these marine microalgal cells.

\section{MATERIALS AND METHODS}

\section{Microalgal culture}

Marine microalgae C. marina, I. galbana, Tetraselmis sp., D. salina, and Nannochloropsis sp. strains were obtained from the Central Institute of Brackishwater Aquaculture, Chennai, India. Freshwater microalgae Chlorella sp. was isolated from pond located at Bharathidasan University campus, using agar plating technique. Indoor algal stock culture was maintained according to Perumal et al. (2012).

\section{Immobilization of microalgae}

The microalgal beads were prepared by the method described by Santos et al. (2002) with minor modifications in respect to alginate and cation solution concentrations. To prepare $100 \mathrm{ml}$ of alginate solution with the required alginate concentration, the alginate was first carefully dissolved by slow stirring in $70 \mathrm{ml}$ of distilled water. A $1.3 \%(\mathrm{w} / \mathrm{v})$ solution of sodium alginate (Himedia, MB114-100G, Mumbai, India) was prepared with warm (room temperature) distilled water, autoclaved (for $15 \mathrm{~min}$ at $120^{\circ} \mathrm{C}$ ), cooled to room temperature, and mixed in a magnetic stirrer until the sodium alginate was completely dissolved. In the remaining $30 \mathrm{ml}$ of distilled water, $3.5 \mathrm{~g}$ sodium chloride (Himedia, RM853-500G) was dissolved to obtain $35 \mathrm{~g} \mathrm{~L}^{-1}$ salinity. Cation solutions were prepared in nanopure water. Beads were formed by adding the alginate solution drop wise by means of a $20 \mathrm{ml}$ syringe $(0.8 \times 40 \mathrm{~mm}$ needle; Braun, Melsungen, Germany), into the cation solution, from a height of approximately $15 \mathrm{~cm}$ and at a rate of approximately one drop per second. Beads were kept stirring in the cation solution for $45 \mathrm{~min}$ to allow complete hardening of the alginate, and washed several times with filtered $(0.45 \mathrm{~m})$ natural seawater to eliminate the remaining cation.

\section{Characteristics of dye wastewater}

The textile wastewater was collected from local dyeing industry located in Karur, Tamil Nadu, India. To understand the TW before treatment, physico-chemical parameters were determined (Table 1) using standard methods (Jenkins and Medsken, 1964; Strickland and Parsons, 1979; APHA, 1998) prior to experiment.

\section{Spectrophotometer analysis}

Scanning was performed between 300 and $1000 \mathrm{~nm}$ by using UVvis spectrophotometer (1800 Shimadzu UV) to determine the maximum absorbance ( $\lambda$ max) wavelength of the diluted $(1: 10)$ untreated textile effluent (Khalaf, 2008). This dye wastewater showed ( $\lambda$ max) maximum absorbance at $350 \mathrm{~nm}$ (Figure 1). The absorbance $(350 \mathrm{~nm})$ was used for further analyses of dye.

\section{Experimental setup}

The first set of experiment deliberated on the effect of sample conditions (Shaking and Stable). Each conical flask $(250 \mathrm{ml}$ round bottom erlenmeyer flasks) was inoculated with 50 numbers of microalgal beads. The alginate beads (without microalgae) were used as control. The flasks with algal beads were kept at $37^{\circ} \mathrm{C}$ in metabolic shakers (RIVOTEK, SELEC RC5100, India) at $200 \mathrm{rpm}$ for shaking condition and without shaking (static condition). The samples were withdrawn at defined time intervals (12 and $24 \mathrm{~h}$ ) and suspended particles from the sample were removed by centrifugation at 7,000 rpm for 20 min using centrifuge (REMI, R8C, G-Force value- 8232 RCF). Decolorization was monitored by measuring the absorbance (according to $\lambda$ max) of the supernatant at $350 \mathrm{~nm}$ using UV- Spectrophotometer. Second set of experiment were studied to the effect of different algal species for dye removal. The sodium alginate beads were prepared using five marine microalgal species (C. marina, I. galbana, Tetraselmis sp., D. salina and Nannochloropsis sp.) and one fresh water microalgal species (Chlorella sp.) with same number of beads added to conical flasks. The samples were collected at 12 and $24 \mathrm{~h}$ time interval and stopped when maximum decolorization was achieved. The 


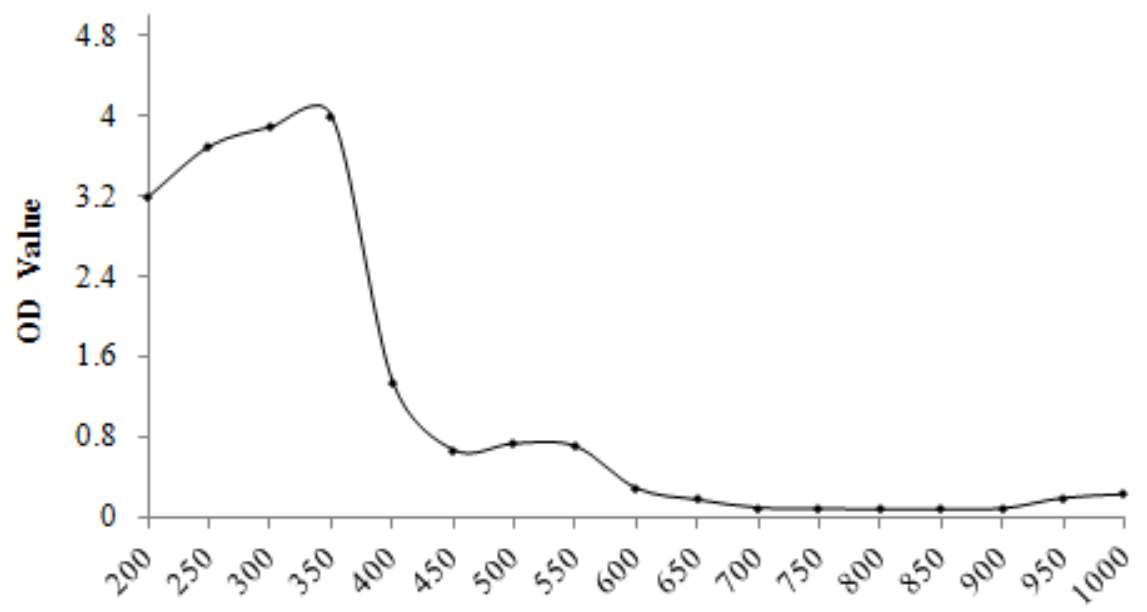

Absorbance (nm)

Figure 1. Spectrophotometer analyses for untreated textile wastewater.

Table 1. The physico-chemical characteristics of untreated textile wastewater

\begin{tabular}{lc}
\hline Parameter & Value \\
\hline $\mathrm{pH}$ & 10.6 \\
Colour & Pink \\
Conductivity $(\mu \mathrm{S})$ & 2,228 \\
Salinity $(\mathrm{ppt})$ & 8 \\
Dissolved oxygen $\left(\mathrm{mg} \mathrm{L}^{-1}\right)$ & 5.9 \\
Temperature $\left({ }^{\circ} \mathrm{C}\right)$ & 23.5 \\
Total suspended solid $\left(\mathrm{mg} \mathrm{L}^{-1}\right)$ & 0.109 \\
COD $\left(\mathrm{mg} \mathrm{L}^{-1}\right)$ & 30.15 \\
Phosphate $(\mu \mathrm{mol} / \mathrm{l})$ & 7.88 \\
Nitrate $(\mu \mathrm{mol} / \mathrm{l})$ & 2.94 \\
Ammonia $(\mu \mathrm{mol} / \mathrm{l})$ & 17.42 \\
Silicate $(\mu \mathrm{mol} / /)$ & 42.27 \\
Nitrite $(\mu \mathrm{mol} / \mathrm{l})$ & 17.89 \\
\hline
\end{tabular}

absorbance was noted according to Telke et al. (2010). The decolorization rate was calculated as follows:

Decolorization $(\%)=\frac{(\text { Initial absorbance })-(\text { Observed absorbance })}{\text { Initial absorbance }} \times 100$

\section{RESULTS AND DISCUSSION}

\section{Characteristics of untreated textile wastewater}

The textile wastewater temperature was $23.5^{\circ} \mathrm{C}$, was highly colored and had alkaline condition with strong and objectionable odour that presents significant disposal or treatment problem. Physico-chemical characteristics of wastewater are given in Table 1.

\section{Effect of treatment method}

Two set of triplicates samples were studied for the discoloration of wastewater (one set at shaker + one set at static condition). The maximum colour reduction (13.66 $\pm 0.2 \%$ ) noticed in shaker condition was recorded at 120 min in incubation, whereas at the static condition it was recorded as $21.77 \pm 0.4 \%$ at $120 \mathrm{~min}$. The results show that the decolorization of dyes was increased with time up to $120 \mathrm{~min}$. However, the rate of dye decolorization was quite slow after 120 min which may be probably due to products inhibition. This observation suggested that initial two hour was significant for dyes decolorization and 


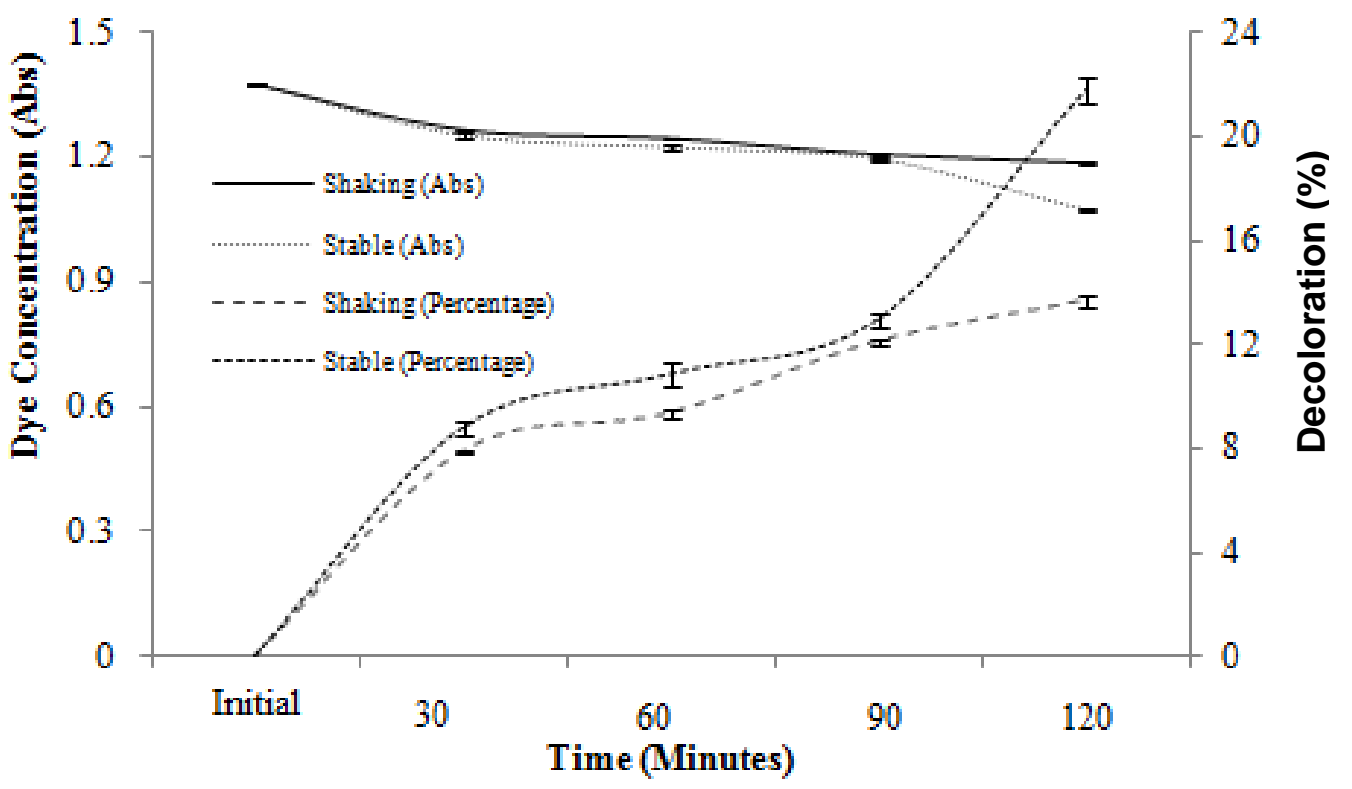

Figure 2. Decoloration of dye wastewater using immobilized microalgal beads with reference to treatment methods.

results were agreed by earlier workers (Khan and Husain, 2007; Arabaci and Usluoglu, 2014). In both (Static and Shaking) condition, experiments were performed until $120 \mathrm{~min}$ beyond which the removal rate of the microalgae decreased. The beads used in static condition proved to be more efficient on colour removal (Figure 2). Earlier studies also revealed the high colour removal from textile wastewater in more static condition than that shaking condition using various biological biomasses like fungi, bacteria, enzymes etc (Sugiura et al., 1999; Jang et al., 2007; Dhanve et al., 2009). The microaerophilic (Static) conditions which resulted in higher colour removal may be due to the presence of oxygen that would normally inhibit the activity of decolorization, resulting in less efficiency of color removal capacity in aerophilic condition by the same organisms (Meiying et al., 2007).

\section{Effect different algal species}

Algae have been found to be potential biosorbents because of their availability in both fresh and saltwater. The biosorption capacity of algae is attributed to their relatively high surface area and high binding affinity (Donmez and Aksu, 2002). Cell wall properties of algae play a major role in biosorption; electrostatic attraction and complexation are known to take part during algal biosorption (Satiroglu et al., 2002). Previous reports have suggested that level of discoloration of dye wastewater using algae can change based on their growing water salinity (Liu et al., 2013). The time dependent experiment showed that the colour removal increased with increasing time as agreed by previous worker (Saraswathi and Balakumar, 2009). They stated that the maximum time is (not exceeding seven days) an ideal way to reduce the colour from the dye wastewater. The percentage of colour reduction using immobilized beads were in the order of I. galbana (55.75\%), fresh water Chlorella sp. (43.77\%), Tetraselmis sp. (41.93\%), C. marina (36.75\%), Nannochloropsis sp. (32.87\%) and D. salina (29.54\%), respectively (Figure 3 ). The present results have proved that $I$. galbana posesses efficient colour removal ability as agreed by Ang (2008). He proved that the I. galbana being suitable for bioremediation and removing pollutants from various effluents compared to Chaetoceros $\mathrm{sp}$ and Tetraselmis sp. Higher decolourization capacity of $I$. galbana can be attributed to size of the cells (Kishore et al., 2006). Wolfe et al. (1998) described that the $I$. galbana play a role in the fate of dispersed oil, it is important to understand how dispersants may influence the bioavailability of pollutants like metals, dye compositions in primary tropic levels of marine food chains. The decolorization of present study (I. galbana; $55.75 \%$ ) were quietly high compared to other workers (Henciya et al., 2013) has been dealt with marine species (Lyngbya sp.; 46.34\%).

The colour removal capacity, especially by using algae, may be attributed to the accumulation of dye ions on the surface of algal biopolymers and further to the diffusion of the dye molecules from aqueous phase onto the solid phase of the biopolymer (Ozer et al., 2006). Extracellular polymers consist of surface functional groups, which enhance sorption of the dye molecules onto the surface of the polymer (floc) during dye removal process. The 


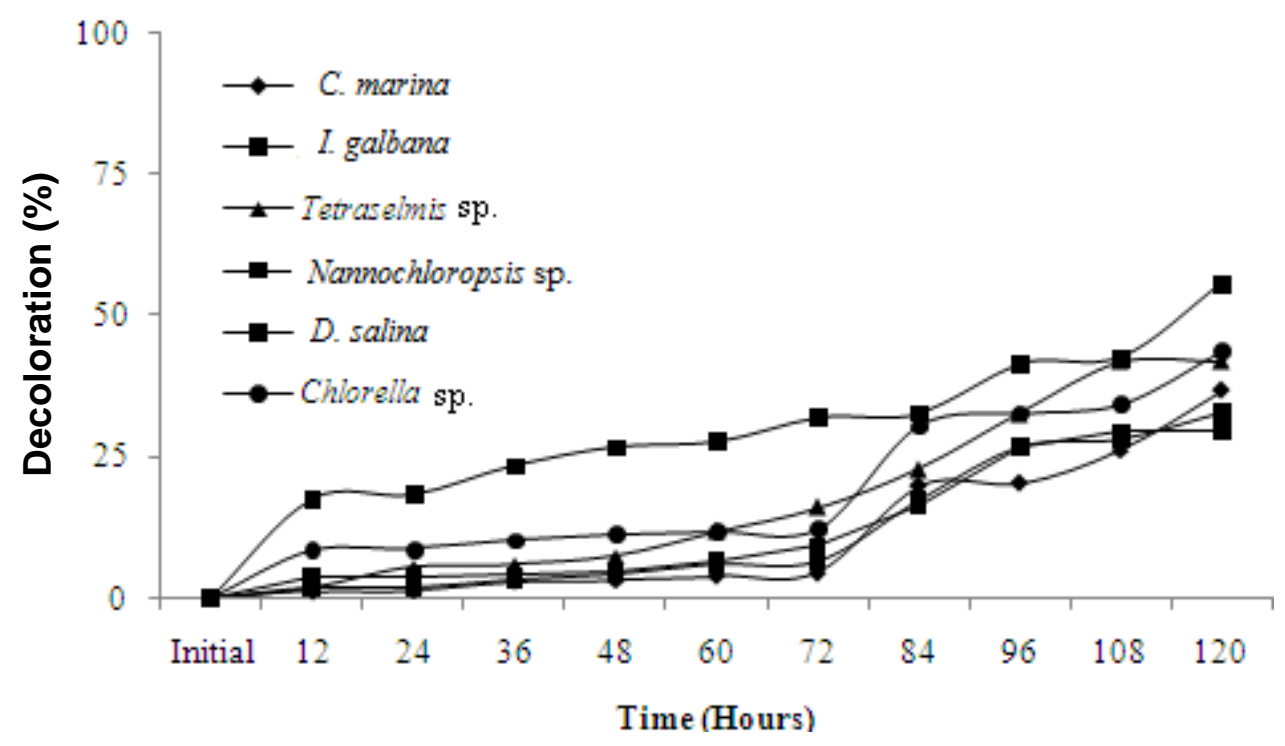

Figure 3. Effect of incubation time on dye removal efficiency (\%) of six microalgal species.

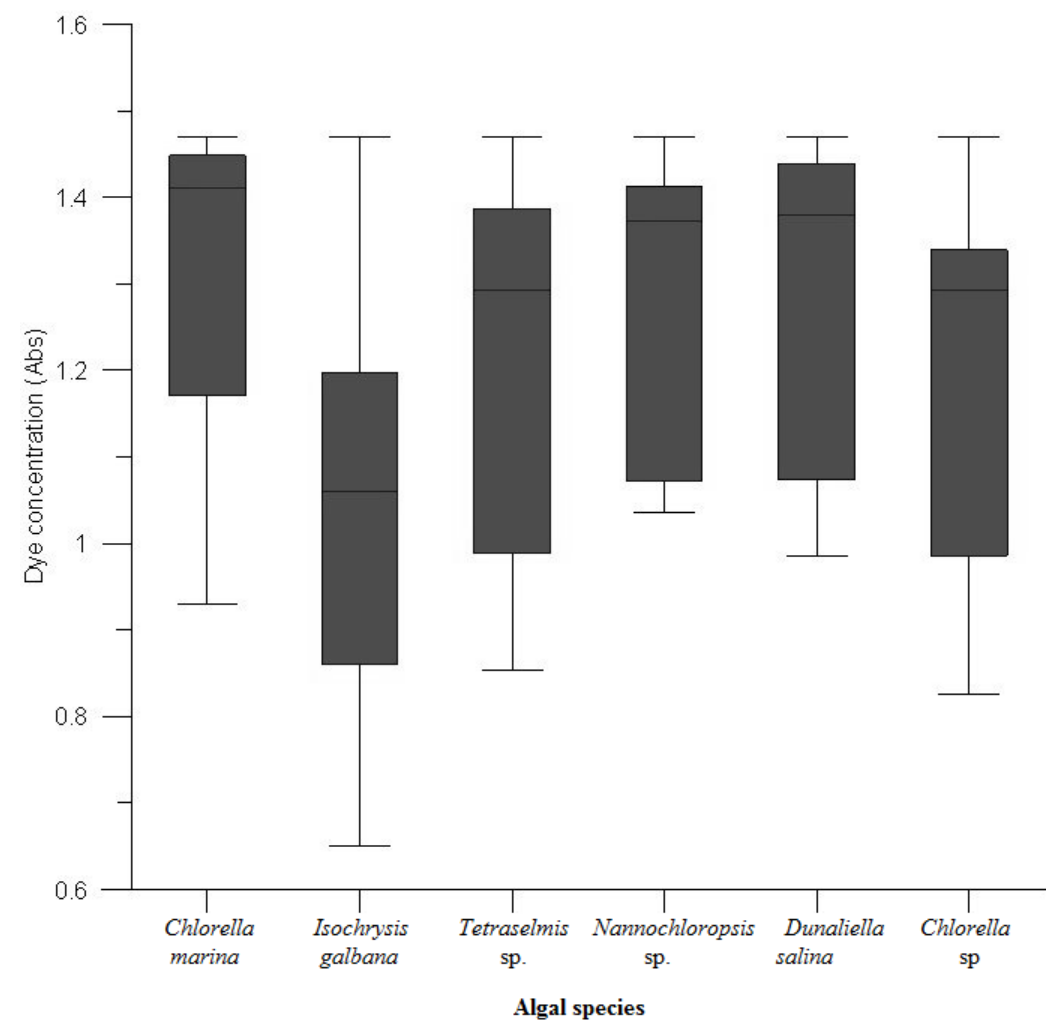

Figure 4. Box-Whisker plot shows the decoloration of dye wastewater using different immobilized microalgal beads.

released metabolic intermediates (long chain biopolymers) which have excellent coagulation capacity along with the dye remaining in the aqueous phase tend to adsorb onto the surface of the polymers and settle (biocoagulation) (Mohan et al., 2002).
Many authors reported that microalgae is a common and effective species for the immobilization and adsorption purposes (Tam et al., 1994; Lau et al., 1998; Abdel Hameed, 2002; Dinesh et al., 2013) (Figure 4). Alginate is the most frequent polymer used for algal immobilization. 
Studies have adequately verified cell viability in the alginate matrix (Vilchez et al., 2001). In a freely suspended algal treatment system, the removal efficiency is often directly related to the cell mass. Increasing the algal biomass would improve the removal efficiency and shorten the retention time (Lau et al., 1995). On the contrary, the super-concentrated cell stocking in the beads, posed a serious leakage problem (Lau et al., 1997) and affects the treatment efficiency by the number of beads in dye wastewater (algal bead concentration).

\section{Conclusion}

Microalgae I. galbana can be considered as an important candidate among the six (five marine and one fresh water) microalgae studied, applicable to efficient removal of synthetic dyes from textile effluents. Similar studies on physiology and biochemical aspects of microalgal farming and fresh methods of immobilization together with coimmobilization of various capable species are necessary to develop a good decolorization method. Immobilized microalgae in alginate will be useful for final polishing of DW after undergoing crucial treatment before discharge. Cartridges of immobilized algae will be the optional system for such purpose as this will take up less land space compared to suspension cultures in raceway ponds. In addition, the effects of $\mathrm{pH}$, contact time and temperature need to be optimized before commercialization.

\section{Conflict of Interests}

The author(s) have not declared any conflict of interests

\section{ACKNOWLEDGEMENT}

Authors thank the Head, Department of Marine Science and authorities of Bharathidasan University for the facilities provided. Authors acknowledge Dr. A. R. Thirunavukkarasu, Principal Scientist, Fish Culture Division, Central Institute of Brackishwater Aquaculture, Chennai, for providing algal culture for our experiments.

\section{REFERENCES}

Ang MY (2008). Use marine micro algae in bioremediation of balm oil mill effluent, Ph. D Thesis, University Malaysia Sabah, Malasiya. P. 85.

APHA (1998). Standard methods for the examination of water and wastewater. American Public Health Association, American Water Works Association, Water Pollution Control Federation, 20th ed. Washington DC, USA. P. 133.

Arabaci G, Usluoglu A (2014). The enzymatic decolorization of textile dyes by the immobilized polyphenol oxidase from quince leaves. Sci. World J. 1-5.

Banat IM, Nigam P, Singh D, Merchant R (1996). Microbial decolorization of textile dye containing effluents: A review. Bioresour. Technol. 58:217-227.

Dhaneshwar N, Ayazloo M, Khataee AR, Pourhassan M (2007). Biological decolorization of dye solution containing Malachite Green by microalgae Cosmarium sp. Bioresour. Technol. 98:1176-1182.

Dhanve RS, Kalyani DC, Phugare SS, Jadhav JP (2009). Coordinate action of exiguobacterial oxidoreductive enzymes in biodegradation of reactive yellow 84A dye. Biodegradation 20:245-255.

Dinesh KS, Santhanam P, Jayalakshmi T, Nandakumar R, Ananth S, Shenbaga DA, Balaji PB (2013). Optimization of $\mathrm{pH}$ and retention time on the removal of nutrients and heavy metal (zinc) using immobilized marine microalga Chlorella marina. J. Biolog. Sci. 13:400-405.

Donmez G, Aksu Z (2002). Removal of chromium (VI) from saline wastewaters by Dunaliella species. Process Biochem. 38: 751-762.

Fewson CA (1998). Biodegradation of xenobiotic and other persistent compounds: the causes of recalcitrance. Trends Biotechnol. 6:148153.

Henciya S, Murali SA, Malliga P (2013). Decolorization of Textile dye effluent by Marine cyanobacterium Lyngbya sp. BDU 9001 with coir pith. Int. J. Environ. Sci. 3:1909-1918.

Jen AC, Wake C, Mikos AG (1996). Review: Hydrogels for cell immobilization, Biotechnol. Bioeng. 50:357-364.

Jenkins D, Medsken L (1964). A Brucine method for the determination of nitrate in ocean, estuarine and fresh waters. Anal. Chem. 36: 61.

Kaushik P, Malik A (2009). Fungal dye decolorization: Recent advances and future potential. Environ. Int. 35:127-141.

Khalaf MA (2008). Biosorption of reactive dye from textile wastewater by nonviable biomass of Aspergillus niger and Spirogyra sp. Bioresour. Technol. 99: 6631-6634.

Khan AA, Husain Q (2007). Decolorization and removal of textile and non-textile dyes from polluted wastewater and dyeing effluent by using potato (Solanum tuberosum) soluble and immobilized polyphenol oxidase. Biores. Technol. 98:1012-1019.

Kishore KK, Krishna Prasad M, Sarma GVS, Murthy VR (2006). Biosorption studies for removal of chromium using immobilized marine alga Isochrysis galbana. Indian J. Mar. Sci. 35:263-267.

Lau PS, Tam NFY, Wong YS (1995). Effect of algal density on nutrient removal from primary settled wastewater. Environ. Pollut. 89: 59-66.

Lau PS, Tam NFY, Wong YS (1997). Wastewater Nutrients (N and P) removal by carrageenan and alginate immobilized Chlorella vulgaris. Environ. Technol. 18:945-951.

Lau PS, Tam NFY, Wong YS (1998). Operational optimization of batch wise nutrient removal from wastewater by carrageenan immobilized Chlorella vulgaris. Water Sci. Technol. 38:185-192.

Liu G, Zhou J, Meng X, Fu SQ, Wang J, Jin R, Lv H (2013). Decolorization of azo dyes by marine Shewanella strains under saline conditions. Appl. Microbiol. Biotechnol. 97: 4187-4197.

Meiying X, Jun G, Goupig S (2007). Biodegradation of textile azo dye by Shewanella decoloration is $\mathrm{S} 12$ under microaerophilic conditions. Appl. Microbiol. Biotechnol. 76:719-726

Mohan SV, Rao NC, Prasad K, Karthikeyan J (2002). Treatment of simulated reactive yellow 22 (azo) dye effluents using Spirogyra species. Waste Manage. 22: 575-582.

Mubarak AD, Suresh A, Praveen Kumar R, Gunasekaran M, Thajuddin $N$ (2011). Efficiency of textile dye decolorization by marine Cyanobacterium, Oscillatoria formosa NTDM02. Afr. J. Basic Appl. Sci. 3:09-13.

Ozer A, Akkaya G, Turabik M (2005). Biosorption of Acid Red 274 on Enteromorpha prolifera in a batch system. J. Hazard. Mater. 126:119127.

Ozer A, Akkaya G, Turabik M (2006). The removal of Acid Red 274 from wastewater: combined biosorption and biocoagulation with Spirogyra rhizopus. Dyes Pigments 71: 83-89.

Perumal P, Balaji PB, Santhanam P, Ananth S, Shenbaga DA, Dinesh Kumar S (2012). Isolation and Culture of Microalgae. Manual on Advances in Aquaculture Technology(ed P. Santhanam), pp.166-181.

Santos MM, Moreno-Garrido I, Goncalves F, Soares AMVM, Ribeiro R (2002). An in situ bioassay for estuarine environments using the microalga Phaeodactylum tricornutum. Environ. Toxicol. Chem. 21:567-574.

Saraswathi K, Balakumar S (2009). Biodecolourization of azodye 
(pigmented red 208) using Bacillus firmus and Bacillus laterosporus. J. Biosci. Tech. 1: 1-7.

Satiroglu N, Yalcinkaya Y, Denizli A, Arica MY, Bektas S, Genc O (2002). Application of $\mathrm{NaOH}$ treated Polyporus versicolor for removal of divalent ions of group IIB elements from synthetic wastewater. Process Biochem. 38:65-72.

Soumya G (2012). An investigation on nutrients and textile dye removal efficacy of seagrass Cymodocea rotundata immobilized beads, $M$. Phil., Thesis, Bharathidasan University, India. p. 86.

Strickland SC, Parsons TR (1979). A practical handbook of seawater analyses. Ottawa. Bulletin of Fisheries Research Board of Canada.

Sugiura W, Miyashita T, Yokoyama T, Ara M (1999). Isolation of Azodye-degrading microorganisms and their application to white discharge printing of fabric. J. Biosci. Bioeng. 88:577-581.

Tam NFY, Lau PS, Wong YS (1994). Wastewater inorganic N and P removal by immobilized Chlorella vulgaris. Water Sci. Tech. 30: 369374.
Telke AA, Joshi SM, Jadhav SU, Tamboli DP, Govindwar SP (2010). Decolorization and detoxification of Congo red and textile industry effluent by an isolated bacterium Pseudomonas sp. SU-EBT. Biodegradation 21:283-296.

Vilchez C, Garabayo I, Marckvichea E, Galvan F, Leon R (2001). Studies on the suitability of alginate-entrapped Chlamydomonas reinhardtii cells for sustaining nitrate consumption processes. Biores. Technol. 78:55-61.

Wolfe MF, Schwartz GJB, Singaram S, Mielbrecht EE, Tjeerdema RS, Sowby ML (1998). Effects of salinity and temperature on the bioavailability of dispersed petroleum hydrocarbons to the goldenbrown algae Isochrysis galbana. Arch. Environ. Contam. Toxicol. 35:268-273. 